\title{
Erratum to: SCADA-based Operator Support System for Power Plant Equipment Fault Forecasting
}

\author{
N. Mayadevi $\cdot$ S. Ushakumari $\cdot$ S. S. Vinodchandra
}

Published online: 27 February 2015

(C) The Institution of Engineers (India) 2015

Erratum to: J. Inst. Eng. India Ser. B

(October-December 2014) 95(4):369-376

DOI 10.1007/s40031-014-0117-9

The name of author, 'S. S. Ushakumari' was wrongly printed in the original publication of this article. The correct name of author should be, 'S. Ushakumari'.

The online version of the original article can be found under doi:10.1007/s40031-014-0117-9.

N. Mayadevi $(\bowtie) \cdot$ S. Ushakumari

Department of Electrical Engineering, College of Engineering

Trivandrum, Trivandrum, India

e-mail: maya@cet.ac.in

\section{S. S. Vinodchandra}

Computer Centre, University of Kerala, Trivandrum, India 